\title{
Organic cotton fabric dyed with dyer's oak and barberry dye by microwave irradiation and conventional methods
}

\author{
DOI: 10.35530/IT.072.01.1755
}

YESIM BANU BUYUKAKINCI

RECEP KARADAG

EMINE TORGAN GUZEL

\begin{abstract}
REZUMAT
Organic cotton fabric dyed with dyer's oak and barberry dye by microwave irradiation and conventional methods

In this work, organic cotton fabrics were dyed using barberry (Berberis vulgaris L.), dyer's oak (Quercus infectoria Olivier) and dyer's oak + barberry (Quercus infectoria Olivier + Berberis vulgaris L.) by microwave irradiation and conventional dyeing methods. They were used in equal percentages. The dyed fabrics were analyzed by different analytical and technical methods. Colouring compounds were analyzed in the dyed fabrics, dye extractions (before dyeing bath and after dyeing bath) by High Performance Liquid Chromatography with Diode Array Detector (HPLC-DAD). Identified coloring compounds based on the dyestuff analysis were berberine, berberine derivative, phenolic acid, ellagic acid, ellegic acid derivatives, gallic acid and gallic acid derivative.

Colour characteristics of all the dyed fabrics were measured by CIEL *a* $b^{*}$ spectrophotometer and $\mathrm{pH}$ values were determined by surface-pH meter. Scanning Electron Microscopy equipped with Energy Dispersive X-ray Spectrometer (SEM-EDX) was used for imaging and elemental analysis of the surfaces of the dyed organic cotton fabrics.

The colouristic and colour fastness properties of the dyed fabrics were investigated and compared with each other. No damage was observed in the fabrics dyed by the microwave and conventional dyeing methods. Almost the same colour yields were obtained in both dyeings using different processing times.

According to the analyses and test results, microwave irradiation method is very eligible compared to conventional dyeing methods, considering coloristic properties of dyed fabrics, time saving and the cost effectiveness wise.
\end{abstract}

Keywords: microwave dyeing, organic cotton, natural dye, HPLC-DAD, SEM-EDX, fastness

Vopsirea țesăturii din bumbac organic cu colorant din stejar și din afine prin iradiere cu microunde și metode convenționale

În această lucrare au fost vopsite prin iradiere cu microunde şi metode convenţionale de vopsire țesături din bumbac organic, folosind coloranţi obţinuti din afine (Berberis vulgaris L.), stejar (Quercus infectoria Olivier) și stejar + afine (Quercus infectoria Olivier + Berberis vulgaris L.). Aceştia au fost utilizaţi în procente egale în băile de vopsire. Tesăturile vopsite au fost analizate prin diferite metode analitice și tehnice. Compușii coloranți au fost analizați în țesăturile vopsite, iar extractele de colorant (din baia iniţială de vopsire şi după vopsire) au fost analizate prin cromatografie lichidă de înaltă performanţă cu detector de matrice diodică (HPLC-DAD). Compușii coloranți identificați pe baza analizei coloranților au fost berberina, derivatul de berberină, acidul fenolic, acidul elagic, derivatul acidului elagic acidul galic și derivatul acidului galic.

Caracteristicile culorilor tuturor țesăturilor vopsite au fost măsurate cu spectrofotometrul CIEL *a*b*, iar valorile $p H$-ului au fost determinate cu un pH-metru de suprafață. Microscopia electronică de baleiaj echipată cu spectrometru de raze $X$ cu dispersie de energie (SEM-EDX) a fost utilizată pentru imagistica și analiza elementală a suprafeței țesăturilor din bumbac organic vopsite.

Caracteristicile culorii și proprietățile de rezistență ale culorii țesăturilor vopsite au fost investigate și comparate. Nu s-a observat nicio deteriorare a țesăturilor vopsite în prezența microundelor sau a metodei convenţionale de vopsire. Au fost obținute randamente tinctoriale similare în cazul ambelor metode de vopsire, folosind timpi de prelucrare diferiţi.

Conform analizelor și rezultatelor testelor, metoda de iradiere cu microunde este eligibilă în comparație cu metodele convenționale de vopsire, având în vedere proprietățile coloristice ale țesăturilor vopsite, economisirea timpului și eficiența costurilor.

Cuvinte-cheie: vopsire cu microunde, bumbac organic, colorant natural, HPLC-DAD, SEM-EDX, rezistența culorii

\section{INTRODUCTION}

Natural organic dyes are obtained from dye plants, dye insects, dye molluscs, lichens, etc. They were used in the textile dyeing from ancient times to the mid to late nineteenth century. Natural dyes are known for their use in dyed of natural protein fibres like wool, silk, mohair, etc. as major areas of application since prehistoric times [1]. Increasing environ- mental awareness has made people realize the importance of living in a world with a clean atmosphere.

Organic cotton fabrics dyed with different percentages of the roots of barberry (Berberis vulgaris L.) via gall oak (Quercus infectoria Olivier) and alum mordant [2]. Tannins and gallotannins are water-soluble polyphenolic secondary metabolites in many plants. 
Tannins are distinguished two main groups according to their structures: condensed tannins (proanthocyanidins) and hydrolyzable tannins. Hydrolyzable tannins are composed of esters of gallic acid (gallotannins) or ellagic acid (ellagitannins), with a sugar core which is usually glucose. Major commercial gallotannin (tannic acid) sources are Turkish gallnut, Chinese gallnut and sumac leaves. Both Turkish and Chinese gallnuts contain a large amount of tannin and gallotannin, (50-70\%), and a small amount of free gallic acid and ellagic acid. Dyer's gall oak (Quercus infectoria) is one of the tannin sources which has historically been used mainly for tanning leather and in the manufacture of inks and dyes [3]. Quercus infectoria has been used for cotton and wool dyeing. As natural dyes show no direct affinity for cotton fabric, such as textiles are treated with Terminalia bellirica before any natural dye. This product serves as a mordant that helps to fix the dye on cotton fibers by providing hydroxyl groups, which act as dye sites [4]. Dyer's oak (Quercus infectoria) presents a variety of pharmacological properties such as anesthetic, astringent, antifungal, antiviral, anti-diabetic, [5, 6], antibacterial [7, 8], larvicidal [9], antiinflammation [10] and wound-healing [11] properties. Many literature sources shows that tannins, especially those of plant origin, have been determined to possess antimicrobial activity. The high tannin (colouring compound) present in oak galls is responsible for its antimicrobial activity. In this work, organic knitting cotton fabrics were dyed using dyer's oak dye (Quercus infectoria Olivier), barberry dye (Berberis vulgaris L.) and dyer's oak-barberry dye (Quercus infectoria Olivier - Berberis vulgaris L.) by a conventional dyeing method and a microwave (MW) dyeing method. The advantages of natural dyes are cost effective, renewable and non-carcinogenic in nature, no disposal problems and have no allergic reaction on skin [12].

Usually, the aqueous extraction method (conventional method) is used to produce natural dyes from dye plant species and needs several hours for extraction. Microwave energy is an alternative method to conventional heating methods because it provides uniform and fast heating - with its easy penetration property into the matter. In recent studies, it has been proven that microwave (MW) methods need shorter process time and save energy [13]. Microwave irradiation has been used for surface modification surface grafting, pre-treatment, dyeing and finishing of textile materials, but its use in natural dyeing processes is limited. Therefore, in the present research, microwave irradiation was used for both extraction of plants and dyeing of natural cotton fabrics.

MW has between $1 \mathrm{~cm}$ and $1 \mathrm{~m}$ wavelength and between $30 \mathrm{GHz}$ and $300 \mathrm{MHz}$ frequencies. In electromagnetic spectrum, MW covers the radio frequencies and infrared radiation [14]. The energy is carried by photon; MW photons is $0.125 \mathrm{~kJ} / \mathrm{mol}$, which is very low considering the necessary energy for chemical bonds breaking. Therefore, the molecular structure of the materials cannot be affected directly by
MW irradiation and the electronic structures of atoms can't change. Microwave absorption can also increase kinetic energy in the molecules [15-18]. Energy is transferred in solids by conduction, convection or radiation of heat, in conventional thermal processing, whereas, the microwave energy is transferred directly in the materials through molecular interaction in the presence of electromagnetic field. It can penetrate the materials and deposit energy throughout the volume of the material. Therefore, microwave is a volumetric heating and it is fast, whereas conventional heating is a surface heating and it is slow (figure 1) [19, 20].

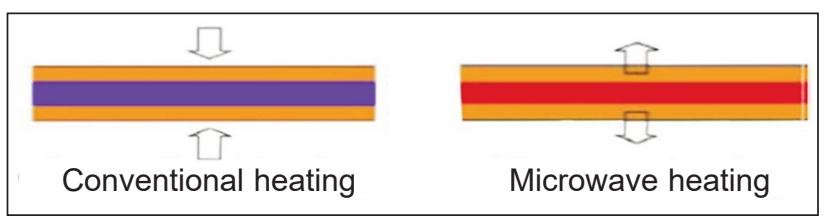

Fig. 1. Volumetric microwave heating and conventiona surface heating

At the present time microwave energy is used in various sectors like chemistry, metallurgy, ceramic, food and textile. MW irradiation methods are safe, ecofriendly and cheap. It also enables dye molecules to diffuse into fabrics (penetrate) instantly and bond more strongly to the materials [14, 16, 21, 22].

\section{Microwave Dyeing of Cotton}

It was recently reported, that microwave irradiation improved the dyeability of cotton and cotton-wool blend fabrics. It was also observed that there was a large increase in dye uptake and rate when compared with conventional heating.

The results of the scanning electron microscope and $X$-ray diffraction pattern indicate that the crystallinity of the fiber decreases with increasing exposure time of MW irradiation.

This decrease in crystallinity is associated with an increase in fibre diameter. Crystallinity has a major impact on properties including fiber strength, flexibility, dye uptake, and colour stability and "lower crystallinity" means "higher amorphous regions" in the cellulose molecules. A fiber which has a lower \% crystallinity is able to absorb water, dyes and other chemicals much more compared to a fiber with high $\%$ crystallinity.

Additionally, fastness tests for washing, rubbing, perspiration as well as fastness to light are relatively lower than their corresponding samples dyed using microwave heating [23, 24].

In recent studies it was observed that the microwave energy doesn't damage the cotton fibers. The colour fastness of microwave dyed cotton fabric is similar or higher compare to the conventional process. MW irradiation provides saving energy greatly by shortening dye time [25].

In this work, $100 \%$ natural cotton fabric was dyed with the natural dyes extracted from dyer's oak (Quercus infectoria) and barberry (Berberis vulgaris) 
via microwave irradiation and conventional methods. Dyer's oak was also used as a mordant for the dyeing quality. Then the dyed fabrics were analysed using different analytical and technical methods.

\section{EXPERIMENTAL WORK}

\section{Material and methods}

\section{Plant, fabric and chemicals}

The dyer's oak (Quercus infectoria Olivier), organic cotton knitting fabric and all chemicals used in this study were supplied by the Turkish Cultural Foundation. $100 \%$ organic knitting interlock cotton fabric was used and the weight of the fabric was 230 $\mathrm{g} / \mathrm{m}^{2}$. Dyestuffs used as reference standard were provided by TCF-DATU (Turkish Cultural Foundation, Cultural Heritage Preservation and Natural Dyes Laboratory in Istanbul-Turkey). The following dyestuff standards were used as references: gallic acid, berberin from Merck and ellagic acid from Alfa Aesar. Hydrochloric acid $(\mathrm{HCl})$, acetonitrile $\left(\mathrm{CH}_{3} \mathrm{CN}\right.$, HPLC grade), trifluoroacetic acid (TFA) and methanol $\left(\mathrm{CH}_{3} \mathrm{OH}\right)$ used as sample preparing and mobile phase for HPLC analysis were also obtained from Merck.

\section{Extraction}

The procedure of the extraction processes is shown in table 1.

Table 1

\begin{tabular}{|c|l|l|}
\hline \multicolumn{3}{|c|}{$\begin{array}{c}\text { EXTRACTION OF BARBERRY, BARBERRY + DYER'S } \\
\text { OAK AND DYER'S OAK DYE }\end{array}$} \\
\hline \multicolumn{3}{|c|}{ Extraction } \\
\hline Method & \multicolumn{1}{|c|}{ Conventional } & $\begin{array}{l}\text { Microwave } \\
\text { irradiation }\end{array}$ \\
\hline Dye plant & $\begin{array}{l}\text { Barberry } \\
\text { Barberry+dyer's oak } \\
\text { Dyer's oak }\end{array}$ & $\begin{array}{l}\text { Barberry } \\
\text { Barberry+dyer's oak } \\
\text { Dyer's oak }\end{array}$ \\
\hline Time & 60 min & 10 min (100 Watt) \\
\hline Temperature & $100^{\circ} \mathrm{C}$ & $90^{\circ} \mathrm{C}$ \\
\hline
\end{tabular}

The microwave irradiation and conventional method were used for the extraction processes. Then the peak areas and heights of the colouring compounds of the extracts were examined by HPLC-DAD for the determination the efficient method.

According to the results of HPLC-DAD, it was decided that it was more appropriate to use extracts obtained according to the MW irradiation for dyeing processes.

\section{Dyeing process}

In this work, $100 \%$ natural cotton fabrics $230 \mathrm{~g} / \mathrm{m}^{2}$ were dyed with natural dyes dyer's oak and barberry according to conventional and microwave irradiation methods. The $100 \%$ natural cotton fabrics were first scoured with $0.5 \%$ non-ionic detergent in the bath with fabric to liquor ratio (F:L) 1:20. Dyer's oak, barberry, barberry and dyer's oak dyes together were used for the dyeing processes, respectively. Dyer's oak was also used as mordant. The scoured cotton fabrics were dyed according the meta-mordanting (simultaneous mordanting) method. In this method dyeing and mordanting processes were carried out in the same bath. Then the dyeings were rinsed thoroughly in tap water and allowed to dry in the open air. All dyeings were carried out in $250 \mathrm{ml}$ glass beakers with and without microwave heating. The dyebath/fabric ratio was 20:1. Dyes were applied at $1 \%$ owf (over weight fiber) depth of shade. According to the conventional method, the dyeings were initiated at $20^{\circ} \mathrm{C}$. The temperature was raised to $60^{\circ} \mathrm{C}$ in 10 minutes and then kept 30 solution.

Microwave-assisted dyeings were carried out in a microwave oven Samsung model - MS23K3515AW (max. output power: 800 watt, 2450 megahertz). Each dye bath which was in the $250 \mathrm{ml}$ beaker was placed into the microwave oven. The temperature of the bath was at first $20^{\circ} \mathrm{C}$. Then it was increased to $60^{\circ} \mathrm{C}$ in 1 minute by using the 800 watt-energy level of the microwave oven. The dye bath was kept at this temperature for 5 minutes by using the 100 wattenergy level. Finally, the beaker was taken out of the oven and the dye solution was cooled. The dyed samples were rinsed with cold tap water.

Three different process-times $(6,8,10 \mathrm{~min})$ were used for dyeing cotton fabrics in $\mathrm{MW}$ conditions. There are no significant differences between the colour characteristics of all the dyed cotton fabric samples which were dyed using microwave irradiation time 6, 8 and 10 minutes. Therefore, in this study, the samples which were dyed according to the shortest microwave irradiation time (6 minutes) were used.

\section{HPLC Analysis (High-Performance Liquid Chromatography)}

The HPLC instrumentations and the HPLC elution program were as described in earlier reports [26-31]. The reference sample and dimethylformamide used in HPLC analysis were supplied by "Sigma Aldrich", and the mobile phases and chemicals used in sample preparation were supplied by "Merck".

\section{Colour measurement and colour Fastness}

Colour measurements of the dyed organic knitting cotton fabrics were carried out a using Konica Minolta CM-2300d Software Spectra Magic NX (D65 illuminant, $10^{\circ}$ standard observer) and the results are shown in tables 2 and 3 . In CIEL*a*b*(1976) coordinates, $L^{*}$ corresponds to brightness, $a^{*}$ to the redgreen coordinate $(+=$ red, $-=$ green $), b^{*}$ to the yellow-blue coordinate $\left(+=\right.$ yellow, $-=$ blue), and $C^{*}$ to vividness-dullness $(100=$ vivid, $0=$ dull $)$ [31]. From the reflectance values $(R)$ in the visible spectrum (380-700 nm) at the maximum absorption wavelength $\left(\lambda_{\text {max }}\right)$ for each dyeing, the corresponding colour strength $(\mathrm{K} / \mathrm{S})$ values of the samples were calculated by using Kubelka-Munk equation [32]:

$$
K / S=(1-R)^{2} / 2 R
$$


where $S$ is the scattering coefficient of the substrate, $K$ is the absorption coefficient of the substrate and $R$ is the reflectance of the dyed samples at $\lambda_{\max }$. Table 4 shows the colorimetric parameters and the colour strength (K/S) values of cotton fabrics dyed with Berberis vulgaris, Berberis vulgaris + Quercus infectoria and Quercus infectoria extracts using conventional and microwave irradiation methods.

Colour fastness tests on the dyed fabrics were examined according to washing (TS EN ISO 105-C06-A1S) and to rubbing (ISO 105-X12) Standards, respectively.

\section{SEM-EDX analysis}

The untreated and dyed cotton fabrics were analyzed by Scanning Electron Microscope equipped with Energy Dispersive X-ray Spectrometer (SEM-EDX) for surface imaging analysis with Secondary electron (SE) detector. In this study, TESCAN VEGA3 SEM (Brno, Czech Republic) and Bruker EDX detector (Massachusetts, ABD) were used. The fabrics were coated using Au/Pd (60/40) target in a sputter coater for surface imaging.

\section{RESULTS AND DISCUSSION}

According to the microwave and conventional methods, the colouring compounds and their peak areas and heights were determined by HPLC-DAD for the dyed samples and dyeing extracts (before dyeing and after dyeing).

Identified colouring compounds based on the dyestuff analysis for dye extracts and the dyed fabrics are shown in table 2 and table 3, respectively. It was observed that using microwave irradiation is more efficient for the extraction than using the conventional method (table 2). According to these results, it was decided that it was more appropriate to use extracts obtained according to the MW irradiation for dyeing processes.

The colouring compounds (phenolic acid, berberine and berberine derivative) were detected in barberry solution and were extracted by using microwave irradiation and conventional methods (table 2).

According to the microwave dyeing method, berberine and berberine derivatives were detected in the barberry dyed fabric. Berberine colouring compound was detected alone in the cotton fabric dyed with the conventional method. Although the extracts of barberry contain phenolic acid and berberine derivatives, the phenolic acid compounds were not bound to the fabrics. Berberine derivatives were detected in the microwave dyed fabric, whereas they were not found in the conventional dyed fabric. The area and height of peaks of berberine and berberine derivatives in the microwave method were higher than the conventional method (table 2). This indicates that the microwave irradiation is more efficient for the extraction of colouring compounds from the barberry for dyeing than the conventional method. This also applied to barberry + dyer's oak dyeing. Berberine derivatives were not found in the fabrics which were dyed with the conventional method. When microwave irradiation was used, the peak height and the peak area of berberine, ellagic acid and its derivatives were higher (table 2). Ellagic acid and its derivatives were also detected in the dyer's oak dyed fabric and extraction.

Identified colouring compounds based on the dyestuff analysis are shown in figures 2-4. Peak

Table 2

\begin{tabular}{|c|c|c|c|c|c|c|c|c|c|}
\hline \multicolumn{10}{|c|}{$\begin{array}{l}\text { IDENTIFIED DYESTUFFS AND THEIR PEAK (AREAS AND HEIGHTS) IN THE EXTRACTS } \\
\text { (BEFORE AND AFTER DYEING) }\end{array}$} \\
\hline \multirow[b]{3}{*}{ Dye plant } & \multirow{3}{*}{$\begin{array}{l}\text { Identified } \\
\text { Dyestuff }\end{array}$} & \multicolumn{4}{|c|}{ Microwave method } & \multicolumn{4}{|c|}{ Conventional method } \\
\hline & & \multicolumn{2}{|c|}{ Total area of peak } & \multicolumn{2}{|c|}{ Total area of height } & \multicolumn{2}{|c|}{ Total area of peak } & \multicolumn{2}{|c|}{ Total area of height } \\
\hline & & $\begin{array}{c}\text { Dye bath } \\
\text { (before } \\
\text { dyeing) }\end{array}$ & $\begin{array}{c}\text { Dye bath } \\
\text { (after } \\
\text { dyeing) }\end{array}$ & $\begin{array}{c}\text { Dye bath } \\
\text { (before } \\
\text { dyeing) }\end{array}$ & $\begin{array}{c}\text { Dye bath } \\
\text { (after } \\
\text { dyeing) }\end{array}$ & $\begin{array}{c}\text { Dye bath } \\
\text { (before } \\
\text { dyeing) }\end{array}$ & $\begin{array}{c}\text { Dye bath } \\
\text { (after } \\
\text { dyeing) }\end{array}$ & $\begin{array}{c}\text { Dye bath } \\
\text { (before } \\
\text { dyeing) }\end{array}$ & $\begin{array}{c}\text { Dye bath } \\
\text { (after } \\
\text { dyeing) }\end{array}$ \\
\hline \multirow{3}{*}{ Barberry } & $\begin{array}{l}\text { phenolic } \\
\text { acid }\end{array}$ & 2199.2 & 2871.6 & 65.2 & 81.3 & 2062.6 & 2137.9 & 55.4 & 57.2 \\
\hline & $\begin{array}{l}\text { berberine } \\
\text { derivative }\end{array}$ & 1713.0 & 1121.8 & 59.6 & 41.9 & 882.5 & 334.0 & 31.5 & 15.5 \\
\hline & berberine & 6966.3 & 7703.9 & 238.0 & 199.9 & 6735.4 & 5466.6 & 167.7 & 115.6 \\
\hline \multirow{4}{*}{$\begin{array}{l}\text { Barberry + } \\
\text { Dyer's oak }\end{array}$} & $\begin{array}{l}\text { ellagic acid } \\
\text { derivatives }\end{array}$ & 13146.7 & 15727.8 & 289.5 & 538.2 & 4384.2 & 10381.5 & 383.0 & 663.5 \\
\hline & ellagic acid & 42832.5 & 46974.8 & 913.9 & 988.5 & 4860.7 & 15417.2 & 86.7 & 355.6 \\
\hline & $\begin{array}{l}\text { berberine } \\
\text { derivative }\end{array}$ & 1312.1 & 653.9 & 55.5 & 22.1 & - & - & - & - \\
\hline & berberine & 6726.6 & 4437.0 & 169.8 & 11.2 & 685.1 & 3204.0 & 18.0 & 66.5 \\
\hline \multirow[t]{2}{*}{ Dyer's oak } & $\begin{array}{l}\text { ellagic acid } \\
\text { derivatives }\end{array}$ & 142010.6 & 16356.0 & 759.8 & 608.0 & 24289.7 & 25063.1 & 674.6 & 838.6 \\
\hline & ellagic acid & 120093.7 & 16766.0 & 2756.0 & 364.7 & 13360.2 & 14765.9 & 302.3 & 376.7 \\
\hline
\end{tabular}




\begin{tabular}{|c|c|c|c|c|c|}
\hline \multicolumn{6}{|c|}{ IDENTIFIED DYESTUFFS AND THEIR PEAK (AREAS AND HEIGHTS) IN THE DYED SAMPLES } \\
\hline \multirow[b]{2}{*}{ Dye plant } & \multirow{2}{*}{$\begin{array}{c}\text { Identified } \\
\text { Dyestuff }\end{array}$} & \multicolumn{2}{|c|}{ Microwave method } & \multicolumn{2}{|c|}{ Conventional method } \\
\hline & & $\begin{array}{c}\text { Total area } \\
\text { of peak }\end{array}$ & $\begin{array}{l}\text { Total area } \\
\text { of height }\end{array}$ & $\begin{array}{c}\text { Total area } \\
\text { of peak }\end{array}$ & $\begin{array}{l}\text { Total area } \\
\text { of height }\end{array}$ \\
\hline \multirow{3}{*}{ Barberry } & phenolic acid & - & - & - & - \\
\hline & berberine derivative & 92.7 & 3.2 & - & - \\
\hline & berberine & 1236.8 & 28.6 & 345.2 & 12.2 \\
\hline \multirow{4}{*}{$\begin{array}{l}\text { Barberry } \\
+ \\
\text { Dyer's oak }\end{array}$} & ellagic acid derivatives & 11569.5 & 2616.3 & 5943.6 & 1315.5 \\
\hline & ellagic acid & 10310.9 & 173.3 & 4684.1 & 69.2 \\
\hline & berberine derivative & 339.1 & 7.7 & - & - \\
\hline & berberine & 2460.0 & 57.3 & 687.9 & 23.3 \\
\hline \multirow{2}{*}{ Dyer's oak } & ellagic acid derivatives & 9649.8 & 2245.3 & 5177.9 & 1174.7 \\
\hline & ellagic acid & 9715.3 & 162.8 & 4895.2 & 76.0 \\
\hline
\end{tabular}

heights of the identified dyestuffs in the HPLC analysis are shown in table 2 (for extracts) and table 3 (for dyed fabrics).

As a result, it was observed that the microwave irradiation is more efficient for extraction and dyeing of colouring compounds than the conventional method (tables 2 and 3 ).
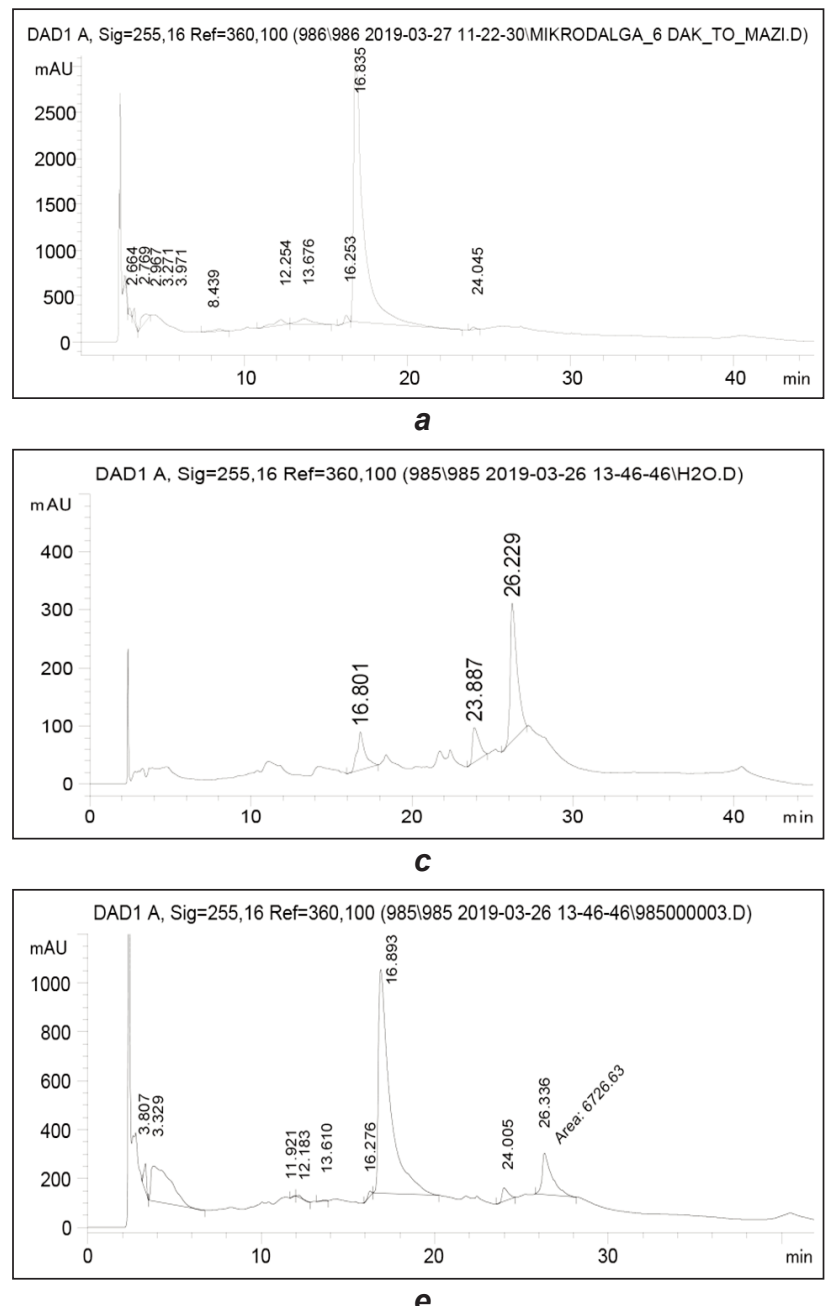

The results of colour values and colour strength $(\mathrm{K} / \mathrm{S})$ of the dyed samples were given in table 4. Using microwave irradiation yielded a significantly deeper colour compared to conventional dyeing method. Table 4 shows that the microwave-dyed cotton fabric with barberry extract is slightly darker, less red, more yellow and slightly saturated $\left(C^{*}=28.70\right)$ compared to
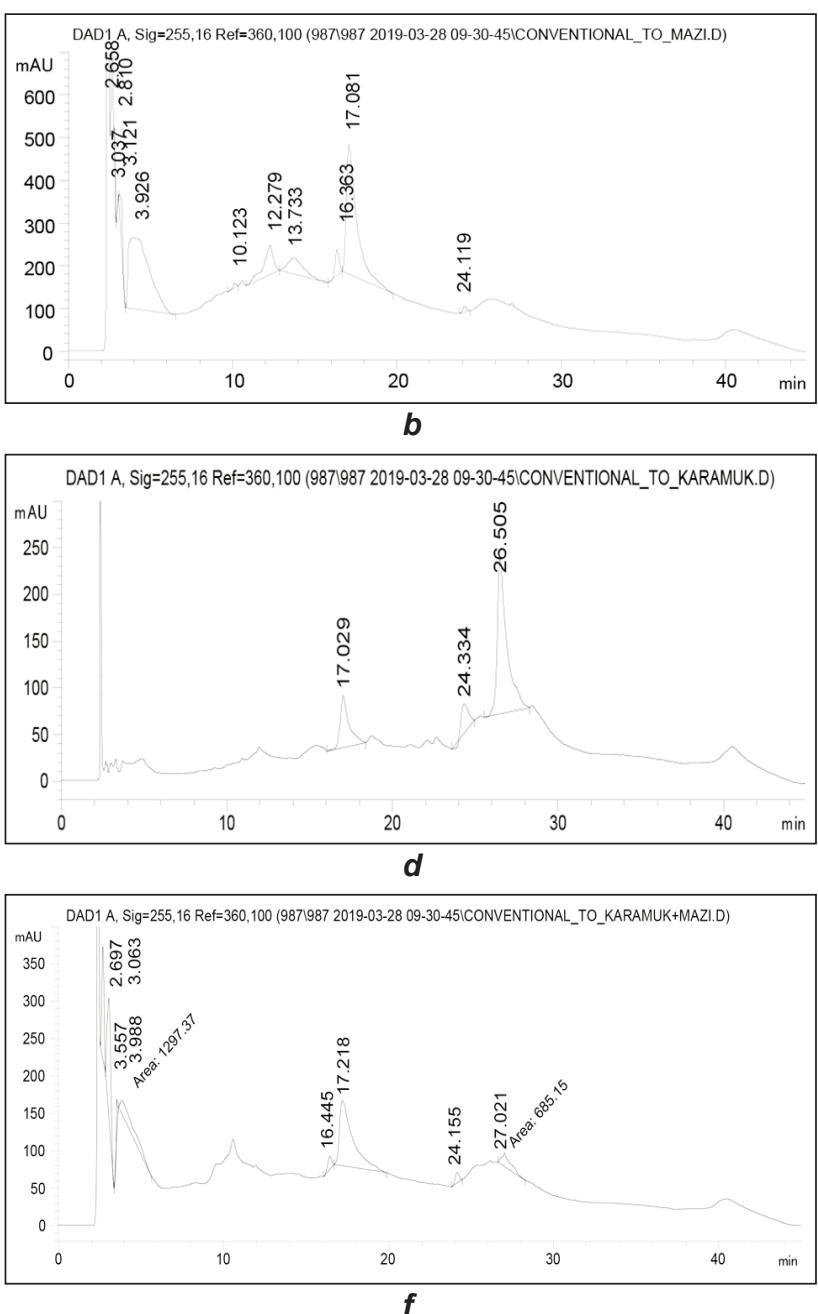

Fig. 2. Chromatograms of extractions: $a$-dyer's oak MW; $b$-dyer's oak conventional; $c$ - barberry MW; $d$ - barberry conventional; $e$-dyer's oak and barberry MW; $f$-dyer's oak and barberry conventional 

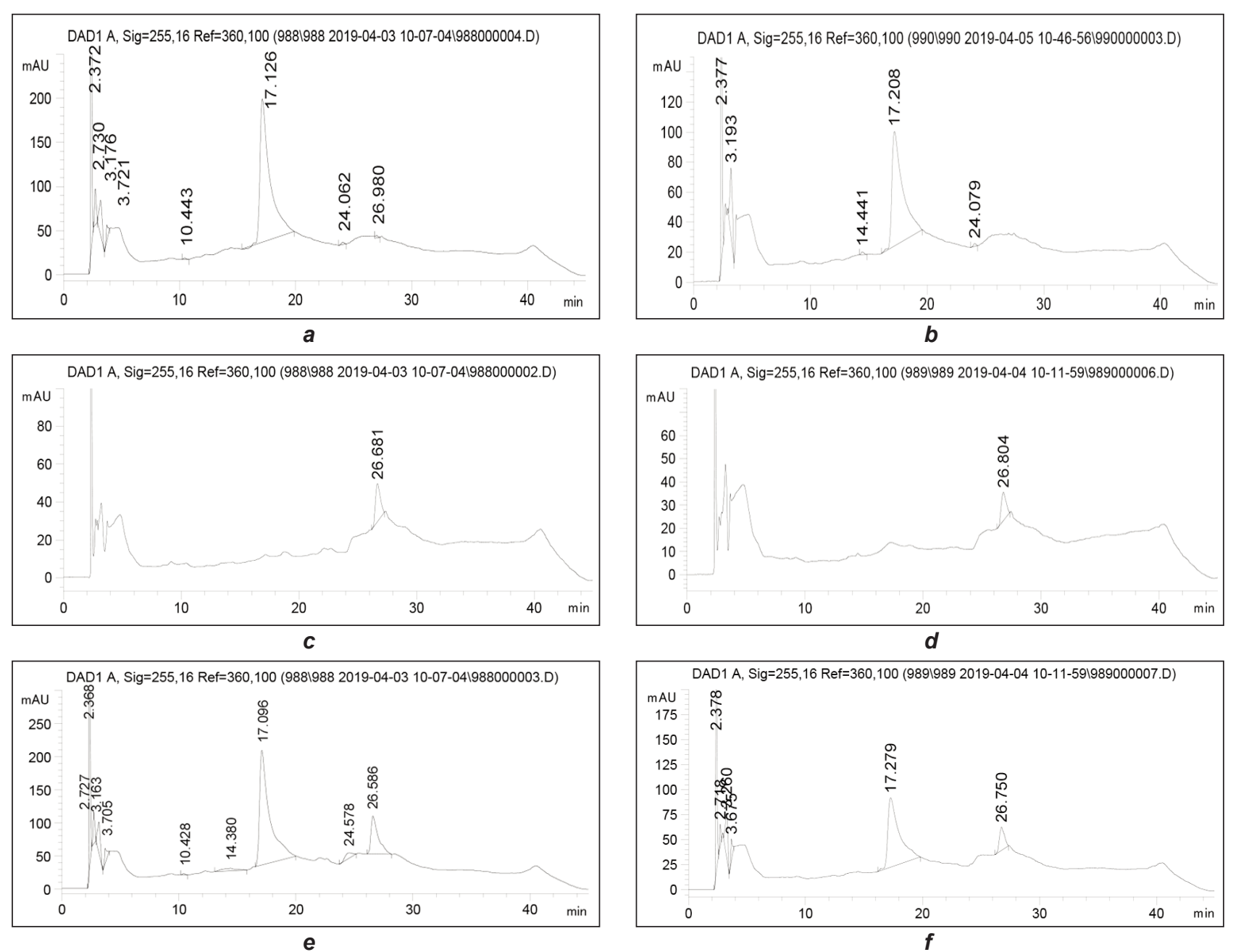

Fig. 3. Chromatograms of the dyed fabrics: $a$-dyer's oak MW; $b$-dyer's oak conventional; $c$ - barberry MW; $d$ - barberry conventional; $e$-dyer's oak and barberry MW; $f$-dyer's oak and barberry conventional
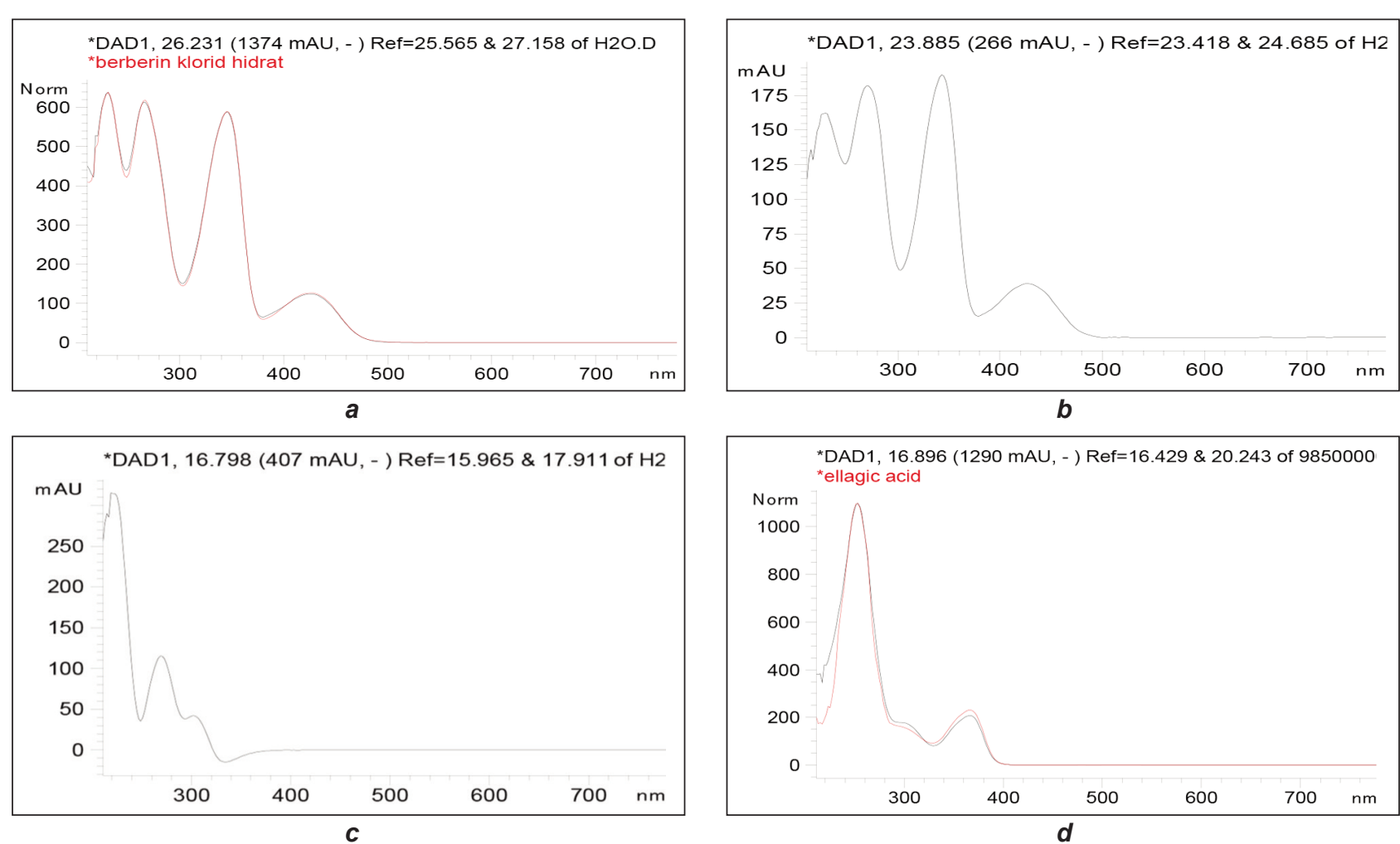

Fig. 4. Spectra of identified colouring compounds: $a$ - berberine; $b$ - berberine darivitives; $c$ - ellagic acid derivative (fenolic acid); $d$ - ellagic acid 
the conventional-dyed samples. The $\mathrm{K} / \mathrm{S}$ values of dyed fabrics dyed with barberry extract are 0.36 and 0.56 for the microwave irradiation and the conventional method, respectively. There is not significant difference in colour strength values between two methods.

Cotton fabrics dyed only with dyer's oak extract yielded similar values for both conventional dyeing and microwave irradiation methods (K/S values: 1.75 $-1.76)$.

In this study, dyer's oak extract was used as mordant. In the meta-mordanting process, barberry and dyer's oak were used simultaneously in the same bath. The microwave-dyed samples with barberrydyer's oak dye were slightly darker, redder, more yellow and more saturated than the conventional-dyed samples. The K/S values are 3.20 and 1.51 for the microwave-dyed fabric and the conventional-dyed fabric, respectively.
All of these results indicate that the samples dyed by microwave irradiation method are slightly better than dyed by the conventional methods, although using a very short dyeing time.

Colour fastness of all the treated samples were examined according to ISO 105-C06 (A1S) and ISO 105-X12:2016 Standards; the results were given in table 5 .

Comparing the two methods, it was observed there were small differences in the color fastness values of the dyed samples. The color change values were found to be 3-4 and 5 for dyer's oak dye using microwave and conventional dyeing methods, respectively. The staining test results of adjacent multifibers were generally found to be 4-5 grey scale ratings. All of the dyed fabrics have excellent fastness levels to rubbing (5).

The SEM images of undyed and dyed fabrics are shown in figure 5 ( $a$ - untreated fabric, $b$ - fabric dyed

COLOR VALUES AND COLOR STRENGTH OF THE UNDYED AND DYED FABRICS

\begin{tabular}{|l|c|c|c|c|c|c|c|}
\hline \multicolumn{1}{|c|}{ Dye } & Method & $\mathbf{L}^{*}$ & $\mathbf{a}^{*}$ & $\mathbf{b}^{*}$ & $\mathbf{C}^{*}$ & $\mathbf{h}^{\circ}$ & $\mathbf{K} / \mathbf{S}$ \\
\hline Undyed fabric & - & 91.81 & 0.66 & 10,06 & 10.09 & 86.25 & 0.10 \\
\hline Barberry & conventional & 89.41 & -2.37 & 22.94 & 23.07 & 95.89 & 0.36 \\
\hline Barberry-Dyer's oak & conventional & 82.98 & 0.34 & 29.13 & 29.13 & 89.34 & 1.51 \\
\hline Dyer's oak & conventional & 82.97 & 1.06 & 22.90 & 22.92 & 87.36 & 1.75 \\
\hline Barberry & microwave & 88.38 & -2.6 & 28.58 & 28.70 & 95.19 & 0.57 \\
\hline Barberry-Dyer's oak & microwave & 80.19 & 0.76 & 39.54 & 39.55 & 88.89 & 3.20 \\
\hline Dyer's oak & microwave & 82.99 & 1.37 & 19.54 & 29.59 & 86.00 & 1.76 \\
\hline
\end{tabular}

Table 5

\begin{tabular}{|c|c|c|c|c|c|c|c|c|c|c|}
\hline \multirow{2}{*}{ Dyed Sample } & \multirow{2}{*}{ Method } & \multirow{2}{*}{$\begin{array}{l}\text { Colour } \\
\text { change }\end{array}$} & \multicolumn{6}{|c|}{ Staining* } & \multicolumn{2}{|c|}{ Rubbing } \\
\hline & & & Wo & PAN & PES & PA & Co & $\mathrm{CA}$ & Dry & Wet \\
\hline Barberry & conventional & 2 & $4-5$ & $4-5$ & $4-5$ & 4 & $4-5$ & $4-5$ & 5 & 5 \\
\hline Barberry-Dyer's oak & conventional & $3-4$ & $4-5$ & $4-5$ & $4-5$ & 4 & $4-5$ & 4 & 5 & 5 \\
\hline Dyer's oak & conventional & $3-4$ & $4-5$ & $4-5$ & $4-5$ & 4 & $4-5$ & 4 & 5 & 5 \\
\hline Barberry & microwave & 2 & $4-5$ & 5 & 5 & 4 & 5 & $4-5$ & 5 & 5 \\
\hline Barberry-Dyer's oak & microwave & 4 & $4-5$ & 5 & 5 & $3-4$ & 5 & 4 & 5 & 5 \\
\hline Dyer's oak & microwave & 5 & 5 & 5 & 5 & 5 & 5 & 5 & 5 & 5 \\
\hline
\end{tabular}

Note: * CA - Cellulose Acetate, Co - Cotton, PA - Polyamide, PES - Polyester, PAN - Acrylic, Wo - Wool.

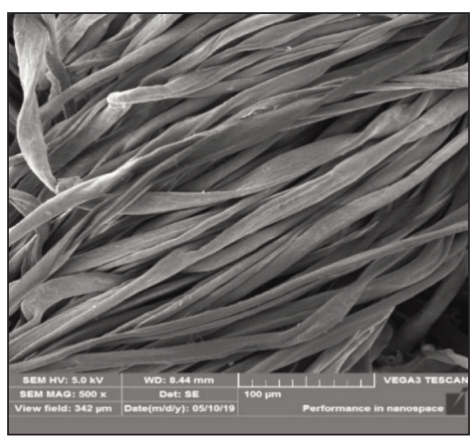

a

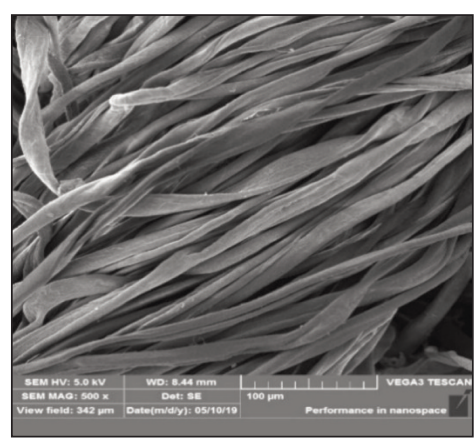

b

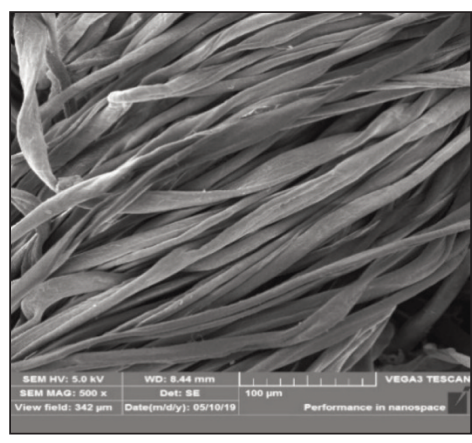

C

Fig. 5. The SEM images: $a$ - undyed; $b$ - conventional dyed; $c$ - microwave irradiation 
conventionally, $c$ - fabric dyed using MW irradiation). It was observed that the fibers dyed with barberry + dyer's oak dye had retained their structures without any damages after the both dyeing processes.

\section{CONCLUSIONS}

It can be concluded that microwave heating enhances the dye uptake of cotton fiber and dyeings especially with Berberis vulgaris-Quercus infectoria can be obtained with good coloristic properties and adequate colour fastnesses.

According to the results of RP-HPLC- PAD analyses for the dye-extract and dyed samples, the quantity of the total colouring compounds at the microwave method are much more than conventional method. The concentration of coloring compounds in the extract is higher in the microwave method. Therefore, the colour properties of the dyed samples have also good results under microwave irradiation.

The dyeing times for the conventional and the microwave methods were about 40 and 6 minutes, respectively. These results show that, the dyeing time were reduced by using of the microwave irradiation, so a great amount of time saving energy conservation and the cost-effectiveness are possible. In addition, this dyeing process is very eco-friendly because of used the natural organic cotton fabric and natural dyes.

Microwave irradiation heating has a promising future in dye extraction from biological sources and sustainable natural dyeings.

\section{ACKNOWLEDGEMENTS}

We would like to thank Dr. Chris Cooksey for a critical review.

\section{REFERENCES}

[1] Karadag, R., Doğal Boyamacılık, Ankamat Matbaacılık San. Ltd. Sti. Turkey, 2007

[2] Deveoglu, O., Karadag, R., Torgan, E., Yildiz, Y., Examination of Dyeing Properties of the Dyed Cotton Fabrics with Barberry (Berberis vulgaris L.), In: Journal of Natural Fibers, 2019, 1-10, https://doi.org/10.1080/ 15440478.2018.1558143

[3] Sariozlu, N.Y., Kivanc, M., Gallnuts (Quercus infectoria Oliv. and Rhus chinensis Mill.) and their usage in health, In: Nuts \& Seeds in Health and Disease Prevention, 2011, 60, 505-511

[4] Gupta, D., Laha, A., Antimicrobial activity of cotton fabric treated with Quercus infectoria extract, In: Indian Journal of Fibre \& Textile Research, 2007, 32, 88-92

[5] Alkan, R., Torgan, E., Karadag, R., The investigation of antifungal activity and durabilityof natural silk fabrics dyed with madder and gallnut, In: Journal of Natural Fibers, 2017, 14, 769-780

[6] Soon, L.K., Hasni, E., Law, K.S., Waliullah, S.S., Farid, C.G., Syed Mohsin, S.S.J., Ultrastructural findings and elemental analysis of Quercus infectoria, In: Oliv. Ann Microsc 2007, 7, 32-37

[7] Alkan, R., Torgan, E., Aydın, C., Karadag, R., Determination of antimicrobial activity ofthe dyed silk fabrics with some natural dyes, In: Tekstil ve Mühendis, 2015, 22: 37-43

[8] Basri, D.F., Fan, S.H., The potential of aqueous and acetone extracts of galls of Quercus infectoria as antibacterial agents, In: Indian J Pharmacol, 2005, 37, 26-29

[9] Redwane, A., Lazrek, H.B., Bouallam, S., Markouk, M., Amarouch, H., Jana, M., Larvicidal activity of extracts from Quercus lusitania var. infectoria galls (Oliv.), In: J Ethnopharmacol, 2002, 79-2, 261-263

[10] Kaur, G., Hamid, H., Ali, A., Alam, M.S., Athar, M., Antiinflammatory evaluation of alcoholic extract of galls of Quercus infectoria, In: J. Ethnopharmacol, 2004, 90, 285-292

[11] Umachigi, S.P., Jayaveera KN, Kumar, C.K.A., Kumar, G.S., Swamy, B.M.W., Kumar, D.V.K., Studies on wound healing properties of Quercus infectoria, In: Trop J Pharm Res, 2008, 7, 913-919

[12] Saha, P., Datta, S., Dyeing of textile fibre using marigold flower as floral dye, In: Colourage, 2008, 55, 52-56

[13] Dabiri, M., Salimi, S., Ghassempour, A., Rassouli, A., Talebi, M., Optimization of microwave-assisted extraction for alizarin and purpurin in Rubiaceae plants and its comparison with conventional extraction methods, In: J. Sep. Sci., 2005; 28, 387-396

[14] Strauss, C.R., Trainar, R.W., Developments in MW-Assisted Organic Chemistry, In: Aust. J. Chem, 1995, 48, 1665-1692

[15] Kappe, C.O., Dallinger, D., Controlled microwave heating in modern organic synthesis: highlights from the 2004-2008 literature, In: Mol. Divers, 2009, 13-2, 71-193

[16] Collins, M.J., Drug Discovery at the Speed of Light, In: R\&D Magazine, 2001, 43, 12, 57-59

[17] Tierney, J.P., Lidström, P. (Eds.), Microwave Assisted Organic Synthesis, Blackwell Publishing Ltd., 2005

[18] Ahluwanlia, V.K., Aggarwal, R., Organic Synthesis: Special Techniques, UK: Alpha Science Int. Ltd., 2001

[19] Regier, M., Schubert, H., Introducing MW processing of food: principles and technologies, in the MW processing of foods, Cambridge, England: M. CRC Press, Woodhead Publishing Limited, 2005, 3-21

[20] Haggag, K., Printing performance of starch carbamate alone or admixture with sodium alginate in reactive dye printing of cotton, wool and cotton/wool blend, In: Am Dyest Rep., 1990, 79, 8, 26

[21] Büyükakıncı, B.Y., Usage of Microwave Energy in Turkish Textile Production Sector, In: Energy Procedia 2012, 424-431

[22] Ghaffar, A., Adeel, S., Habib, N., Jalal, F., Effects of Microwave Radiation on Cotton Dyeing with Reactive Blue 21 Dye, In: Polish Journal of Environmental Studies, 2019, 28, 3, 1-5

[23] Reddy, N., Yang, Y., Properties and potential applications of natural cellulose fibers from the bark of cotton stalks, In: Bioresour Technology, 2009, 100, 14, 3563-3569, https://doi.org/10.1016/j.biortech.2009.02.047 
[24] Haggag, K., Elshemy, N.S., Nasef, N.A., Enhancement of Cotton and Cotton/Wool Blend Dyeability by Microwave Heating, In: Research Journal of Textile and Apparel information, 2012, 16

[25] Huang, K.S., Wu, W.J., Cha, I.C., Effect of pretreatment with low molecular weight chitosan on the dyeability of cotton fabrics, In: Research Journal of Textile and Apparel information, 2007, 11, 3, 54-59

[26] Deveoglu, O., Karadag, R., Yurdu, T., Qualitative HPLC determination of main anthraquinone and lake pigment contents from dactylopius coccus dye insect, In: Chemistry of Natural Compounds, 2011, 47, 103-104

[27] Deveoglu, O., Torgan, E., Karadag, R., Identification by RP-HPLC-DAD of natural dyestuffs from lake pigments prepared with a mixture of weld and dyer's oak dye plants, In: Journal of liquid chromatography \& related technologies, 2012, 35, 331-342

[28] Deveoglu, O., Torgan, E., Karadag, R., The characterisation by liquid chromatography of lake pigments prepared from European buckthorn (Rhamnus cathartica L.), In: Pigment \& Resin Technology, 2012, 41, 331-338

[29] Deveoglu, O., Cakmakcı, E., Taskopru, T., Torgan, E., Karadag, R., Identification by RP-HPLC-DAD, FTIR, TGA and FESEM-EDAX of natural pigments prepared from Datisca cannabina L, In: Dyes and Pigments, 2012, 94, 437-442

[30] Deveoglu, O., Erkan, G., Torgan, E., Karadag, R., The evaluation of procedures for dyeing silk with buckthorn and walloon oak on the basis of colour changes and fastness characteristics, In: Coloration Technology, 2013, 3, 129, 223-231

[31] Karadag, R., Torgan, E., Erkan, G., Dyeing Properties and Analysis by RP-HPLC-DAD of silk fabrics dyed with madder (Rubia tinctorum L.). Journal of Textile Science and Engineering, 2014, 4, 2,1-5

[32] Park, J., Instrumental Colour Formulation: A Practical Guide, JSDC. Bradford, 1993

\author{
Authors: \\ YESIM BANU BUYUKAKINCI ${ }^{1}$, RECEP KARADAG ${ }^{2}$, EMINE TORGAN GUZEL ${ }^{3}$ \\ ${ }^{1}$ Istanbul Aydin University, Engineering Faculty, Department of Textile Engineering, \\ Inonu Cd. No 38, Istanbul, Turkey \\ ${ }^{2}$ Istanbul Aydin University, Faculty of Fine Arts, Department of Fashion and Textile Design, \\ Inonu Cd. No 38, Istanbul, Turkey \\ ${ }^{3}$ TCT Cultural Heritage preservation and natural dye laboratory, Turkey \\ Corresponding authors: \\ YESIM BANU BUYUKAKINCI \\ e-mail: byesimb2@gmail.com \\ RECEP KARADAG \\ e-mail: recepkaradag@aydin.edu.tr
}

